\title{
PORTRAIT OF THE EU AS A RATIONAL AGENT: COLLECTIVE REASON AND DEMOCRATIC DEFICIT
}

\begin{abstract}
Vesco Paskalev*
Summary: In the present article I take a critical view of the well-known discursive dilemma which captures the difference between governance by collective reasoning and governance responsive to majoritarian will. I identify a problem with the solution preferred by the republican theory which I call the rationality gap and suggest that in principle deliberation in the public sphere may bring the two ends together, thus avoiding the gap. Then I look at the European Union (EU) through the prism of civic republicanism and analyse it as an example of a system which collectivises reason. From such a perspective, the notorious democratic deficit is explainable as a contradiction between collective reason and popular will. In principle, pan-European deliberation could close the gap there, too. However, it is obstructed by competition from spontaneous deliberation in the existing national public spheres. The latter are more robust and for that reason the rationality gaps arising there are closed faster so that national public opinions polarise and defend 'national' interest against further deliberative challenges at the upper level. I argue that the notion of competition is useful to explain why, despite the development of common democratic institutions at the EU level and despite the emergence of a weak panEuropean public, the deficit is bound to persist.
\end{abstract}

\section{Collectivising reason}

\subsection{The discursive dilemma}

In 1986 Lewis Kornhauser and Lawrence Sager ${ }^{1}$ identified a paradox in collective decision-making which has haunted political and legal theory ever since. Philip Pettit, followed by a constellation of authors, have generalised the original paradox to make it a powerful lens for understanding political authority and many of the problems it faces. ${ }^{2}$ The

\footnotetext{
Vesco Paskalev is a lecturer in EU Law at the University of Hull. A very early draft of this article was published as EUI Working Paper 19/2012. I would like to thank George Vasilev for his very helpful comments.

1 Lewis A Kornhauser and Lawrence G Sager, 'Unpacking the Court' (1986) 96 Yale Law Journal 82.

2 His core argument first appeared in Philip Pettit, 'Deliberative Democracy and the Discursive Dilemma' (2001) 35 Philosophical Issues (Supplement of Noûs) 268. For a survey of the later developments, see Christian List and Clemens Puppe, 'Judgement Aggregation' in Paul Anand and others (eds), The Handbook of Rational and Social Choice (OUP 2009).
} 
dilemma is the following: whenever a reasoned decision has to be taken by a collective decision-maker (either by a small board or a large population) there are two possible routes. First, its members can assess the factual premises relevant for the decision independently, reach their own conclusions and then, on the basis of these individual conclusions, determine the common decision on the issue by majority voting. Alternatively, they can decide on the premises together, eg vote on each of the relevant premises, ${ }^{3}$ and then, on the basis of the common assessment of the premises, embrace the outcome which follows from these premises. The two procedural modes will often yield mutually contradicting outcomes: 'socially aggregating the conclusion-judgement gives us a different result from socially aggregating the premise-judgement'. 4

This can be illustrated by the following example. Let us suppose that an authority headed by a board of three decision-makers is considering a certain policy to mitigate climate change. Suppose that it is undisputed among them that there are three relevant premises the cumulative availability of which warrants the adoption of the policy. ${ }^{5}$ These are: $\mathrm{P}_{1}-$ climate change is a real threat to society, $\mathrm{P}_{2}$-the proposed policy will actually prevent or at least mitigate climate change, and $\mathrm{P}_{3}-$ the cost of the policy is economically bearable. However the members' beliefs on each of the premises differ as per Matrix 1:

$\begin{array}{ccccc}\text { Members } & \begin{array}{c}\mathrm{P}_{1}: \text { Climate } \\ \text { threat real? }\end{array} & \begin{array}{c}\mathrm{P}_{2}: \text { Change } \\ \text { preventable? }\end{array} & \begin{array}{c}\mathrm{P}_{3}: \text { Cost } \\ \text { feasible? }\end{array} & \begin{array}{c}\text { Individual } \\ \text { conclusions: }\end{array} \\ \mathrm{A} & \text { No } & \text { No } & \text { Yes } & \text { No } \\ \mathrm{B} & \text { Yes } & \text { Yes } & \text { Yes } & \text { Yes } \\ \mathrm{C} & \text { Yes } & \text { Yes } & \text { No } & \text { No } \\ \begin{array}{l}\text { Collective } \\ \text { beliefs: }\end{array} & \text { Yes } & \text { Yes } & \text { Yes } & ?\end{array}$

Apparently, there is a majority believing that each of the premises obtains. Therefore, if the panel decides by voting on each of the premises, the decisions on all three will be such that warrant the adoption of the policy. However, if the panel does not decompose the issue to the separate premises, but each of the members makes up his or her own mind

\footnotetext{
3 In most of the examples, this determination is done by simple majority voting, but the result holds for any other judgment aggregation function such as unanimity, supermajority, etc. See Christian List and Philip Pettit, 'Aggregating Sets of Judgments: An Impossibility Result' (2002) 18 Economics and Philosophy 89.

4 Pettit (n 2) 273.

5 To keep things simple throughout the paper, I shall take the premises and the whole logical framework to be undisputed. Certainly, in actual decision-making for different groups, different considerations may be relevant.
} 
whether to adopt or reject the measure itself, there is a majority against the policy. Thus, the outcome in the bottom-right cell will differ, depending on whether the decision is taken in premise-wise mode (PWM) or in conclusion-wise mode (CWM). It is worth noting that sometimes all members of the panel may individually oppose the policy; yet, it is collectively rational to have it adopted (in the example above, this would be the case if A judges $\mathrm{P}_{2}$ to be true but $B$ judges it to be false). Whenever this is so, the panel will hold the two opposite views at the same time - a collective opinion in favour of the policy and personal views of all members against it. ${ }^{6}$

Certainly, the actual occurrence of this contradiction depends on the distribution of members' judgments on the premises; however, in the complex policy-making of today, distributions where the contradiction does arise will be common. Even though the original paradox was identified in cases of jury trial where the premise-conclusion relationship was specified by mandatory legal rules, the result can be generalised: 'a paradoxical distribution of views can arise in any group of three or more persons faced with a decision that can be broken down into at least two constituent sub-decisions'. ${ }^{7}$ Even if the decision-makers are not formally bound to follow any doctrinal rule, the propositions they officially endorse are normally expected to be justified by certain reasons and to exhibit a measure of integrity. ${ }^{8}$ Thus, formal logic, commonsense or recognised scientific laws may bind them, not unlike the legal doctrine binding the courts. This is more interesting than it may appear when applied to regulators or legislators who are typically considered to have more discretion than courts. Nonetheless, they often face the integrity challenge. ${ }^{9}$

Thus, whenever social choices are explicitly made on the basis of reasons, it is likely that various majorities support each of the reasons, yet a majority opposes the conclusion they entail. This will also hold if the decision-making body is extended beyond the three members to the

\footnotetext{
6 This distinctive opinion that a collective may form is the ground on which Pettit and Christian List maintain that groups may be agents of their own right. See Philip Pettit, 'Groups with Minds of Their Own' in Frederick F Schmitt (ed), Socializing Metaphysics: The Nature of Social Reality (Rowman \& Littlefield Publishers 2003); and also Christian List and Philip Pettit, Group Agency: The Possibility, Design and Status of Group Agents (OUP 2011).

7 Lewis A Kornhauser and Lawrence G Sager, 'The Many as One: Integrity and Group Choice in Paradoxical Cases' (2004) 32 Philosophy \& Public Affairs 249.

8 A system satisfies the principle of integrity if 'the different propositions it supports are consistent with each other'. See Christian List and Philip Pettit, 'On the Many as One: A Reply to Kornhauser and Sager' (2005) 33 Philosophy \& Public Affairs 377, 378. Consistency is judged according to logic, commonsense or some other set of rules external to the decision-making system.

9 Note that although for the sake of simplicity in this article I discuss only the social aggregation of beliefs and not of preferences, when the preferences are aggregated the results may be similar if the decision-makers are required to justify their choices by giving some reasons.
} 
whole population, or, more interestingly, to any kind of body which takes into account the relevant premise-beliefs of the population. ${ }^{10}$

Pettit calls the uneasy choice between the two modes of decisionmaking the discursive dilemma and describes it as follows:

going the conclusion-driven way means adopting a course that is inconsistent with the premises endorsed by the group and going the premise-driven way means adopting a course that a majority individually reject. Going the first way means sacrificing collective rationality for the sake of responsiveness to individuals, going the second means sacrificing responsiveness to individuals for the sake of collective rationality. ${ }^{11}$

Throughout his work, Pettit forcefully argues for the collectivisation of reason, ${ }^{12}$ although he acknowledges that in this way responsiveness to individual wills (ie to their aggregation into a 'popular will') will be lost. For him, such frustration of the popular majority is a price worth paying for the gains in collective rationality. In choosing this way, he finds himself in good company - think of the Federalist papers for example but his reason for doing so is his republican understanding of freedom as independence from arbitrary power. ${ }^{13}$ Apparently, a CWM decision is arbitrary, for it is not premised on any reasons which are collectively supported, so PWM should always be preferred.

This is a normative claim which is not uncontroversial, but there is also a pragmatic rationale to go that way: the capacity of the group to set its goals and to choose the appropriate means to achieve them (ie to act as an agent). ${ }^{14}$ Not all groups need to do that. For example, the group of all passengers in a coach may need to decide collectively whether the music and the air-conditioning should be turned on or off, and there is no reason why their collective decisions even on related issues should be consistent. However, some groups with regard to some issues need to go beyond this. The inhabitants of a city have good reasons to pursue certain common goals, like the prevention of crime in the city. Such purposive communities should adopt consistent decisions as a practical

\footnotetext{
10 The panel members may decide not whether $\mathrm{P}_{1}-\mathrm{P}_{3}$ are true or false, but whether their constituencies or the electorate as a whole believe they are true or false.

11 Pettit (n 2) 274.

12 Note that collective reason should not be equated to what John Rawls and others call public reason; collective reason can be specified as the outcome of the premise-wise procedure. Informally, decisions are collectively reasonable when they are consistent with each other and are also supported by the reasons for each other.

13 Philip Pettit, Republicanism: A Theory of Freedom and Government (Clarendon 1997).

14 It is interesting to note that this is prompted also by the etymology of the word. See Josiah Ober, 'The Original Meaning of "Democracy": Capacity to Do Things, Not Majority Rule' (2008) 15 Constellations 1.
} 
matter - otherwise they will undermine their own capacity to achieve the purposes. The commitment to certain purposes is a social and not moral fact; the commitment may be a matter of deliberately adopted positive law or of implicit background understanding. These groups need to act as agents and therefore their collective decisions need to exhibit a certain degree of consistency and rationality. When they face the discursive dilemma, such groups must opt for PWM rather than CWM in order to collectivise reason. ${ }^{15}$

The virtues of collective reason and republican theory have already gained sufficient attention in the academic literature. However, there is one problem which has seemingly been ignored so far, which I call the rationality gap and I will turn to it in 1.3 below. Although the problem recurs whenever reason is collectivised, it seems that most polities which collectivise reason can solve it, and deliberation in the public sphere may close the rationality gap. I will make the bold claim that most contemporary polities achieve some measure of integrity in the republican sense, and in the second part of the article I will show how the European Union (EU) does so. Thus, it is bound to face the rationality gap. Unlike many other polities, however, it fails to close it, and in the third part I will suggest why.

Note that even though I have espoused civic republicanism and the theory of deliberative democracy which are highly normative, for the most part this article is analytical. In the first part, I expose what I see as a problem arising in every democracy and discuss the way I believe democracies do solve it. In the second part, I interpret the existing empirical literature on the EU to argue that it collectivises reason. The third part also starts from the empirical literature, but it is speculative and goes beyond the empirical to make some suggestions which are still to be tested.

I shall start with a discussion on how actual polities collectivise reason in practice.

\subsection{Collectivised reasoning in the real world}

In the abstract PWM model, it seems that all premise judgments are taken simultaneously, but this need not be so. Pettit explicitly notes that the reason can be (and needs to be) collectivised also diachronically and suggests that this can be implemented for example by straw poll or sequential voting. ${ }^{16}$ Neither seems to be implemented verbatim in practice

\footnotetext{
15 Pettit (n 6) and also List and Pettit (n 6).

16 See List and Pettit ( $\mathrm{n}$ 8). In the sequential priority procedure, the propositions on the public agenda are prioritised in a certain way so that the subsequent proposition is voted upon only if it is not entailed by those already decided. In straw polls, a vote pro tempore is taken on each new proposition and if the result contradicts what is entailed by a previ-
} 
anywhere, yet any authoritative decision, which takes for granted what has been decided previously, is in a sense premised on them. ${ }^{17}$ This is collective reasoning in a broader sense - PWM voting is only the paradigmatic model, but any polity which has some mechanisms ensuring that it systematically displays integrity achieves a degree of collective rationality.

There is a great variety of institutional devices which bring about collective rationality in such a sense. For Pettit, this happens mainly through the depoliticisation of certain issues and areas of decisionmaking, ie when they are assigned to various 'contestatory institutions' such as constitutional courts which reduce the 'hands on power' of the majoritarian organs ${ }^{18}$ and by indicative representation via consultative bodies and arm's length appointees. ${ }^{19}$ To these I would add many of the traditional constitutional principles, such as the separation of powers, judicial review, the duty to give reasons, etc. Certainly, they were not meant to collectivise reason, yet they can all be understood as ways to bring about the integrity of collective decisions in the republican sense. ${ }^{20}$ Thus, in republican polity, citizens have an effective opportunity to challenge the decisions of their own representatives on the grounds of the reasons for which they are adopted; such contestations are to ascertain that the governance is according to democratically persuasive reasons and that collectively unreasonable decisions are avoided. Conversely, to the extent that citizens can challenge the grounds on which authoritative decisions are taken, these decisions are non-arbitrary and satisfy the republican imperative. While any contemporary polity collectivises reason in this broader sense, exemplary contestatory institutions are nowhere more common than in the European Union. Not surprisingly, its raison d'être is recognised to be the rationalisation of collective governance. I will turn to this in the second part of this paper.

To see how contestation, and in particular the informal participation of citizens, may contribute to the rationalisation of collective decisions,

ous decision, a vote on which of the two should be revised is taken. For a more detailed discussion of the sequential priority decision procedure, see Christian List, 'A Model of Path Dependence in Decisions over Multiple Propositions' (2004) 98 American Political Science Review 495. For straw polls as a method to discipline reasoning, see Philip Pettit, 'Rationality, Reasoning and Group Agency' (2007) 61 Dialectica 495.

17 Indeed, all institutions and officials work on the assumption that laws are consistent with each other and, when this is clearly not the case, the later law is presumed to have repealed the former (lex posteriory derogat legi priori).

18 Philip Pettit, 'Depoliticizing Democracy' (2004) 17 Ratio Juris 52, 63.

19 See Philip Pettit, 'Representation, Responsive and Indicative' (2010) 17 Constellations 426.

20 These may be contrasted to the electoral institutions, which are ways to make them responsive to collective (aggregated) preferences. The opposition is very crude, as elected representatives are also under pressure to act according to publicly supported reasons, and at least sometimes they do so even against the tide of popular opinion. 
consider again the example of the proposed climate change bill. In an actual polity, the decision on $\mathrm{P}_{1}$ and even $\mathrm{P}_{2}$ may be effectively out of the control of the panel members. Even if they are formally empowered to decide according to their own judgment, this may be prejudiced or precluded by the position of the International Panel on Climate Change (IPCC), for example. Members do not have to be obliged to defer to the IPCC, indeed they rarely are, yet it would be sufficient if they cannot publicly reject its assertion. Similarly, their position on $\mathrm{P}_{3}$ may be kept in check by another authoritative body, like the Office of Management and Budget of the US Congress, an authoritative think tank, or, in the case of the EU, the example of the other Member States. This may take place over time too - once the policy is implemented it will feed back evidence relevant for its justification which can reverse some of the opinions. ${ }^{21}$ Thus, any institution or organisation which provides credible information concerning the premises which justify a policy can sway opinions.

An actual example of the effect of such information on the decision-making and justification of authority occurred during the recent authorisation of a GMO potato for cultivation in the EU. The European Food Safety Authority (EFSA) had issued a non-binding opinion that new GMOs can be authorised only if there is no risk that they can confer resistance to antibiotics valuable in human medicine. When evaluating the GMO potato, EFSA recognised that there is a small risk that it may confer resistance to certain antibiotics, but they were judged not to be important for human medicine so it recommended authorisation. In the meantime, however, the World Health Organisation (WHO) issued a report, completely unrelated to the case, that the affected antibiotics are important for human medicine. With this information, the NGOs participating in the process contested the opinion of EFSA. Although the Commission turned a blind eye and deferred to EFSA, as it usually does, this took a toll on the credibility of EFSA and provided grounds for several Member States to challenge the decision in a case which is currently pending. Obviously, neither EFSA nor the Commission is required to defer to the WHO or to the NGOs bringing forward this information; this would constitute the degeneration of democratic institutions. The decision-makers should not suspend their own judgments on the relevant premises; however they must take into account the new information and revise either their position, or their own earlier judgments to restore consistency. The moral of this story is that contestations may make the premises which justify certain policy choices pivotal for the choice, which leads to more collectively rational decisions as per the model above. It also suggests

${ }_{21}$ Sabel and Zeitlin provide numerous examples in the context of the EU. See Charles F Sabel and Jonathan Zeitlin, 'Learning from Difference: The New Architecture of Experimentalist Governance in the EU' (2008) 14 European Law Journal 271. 
that if decision-making is made more sensitive to new information, the 'soft power' of agents with no formal authority is increased. The success of citizens' participation depends on the information they can provide, but also on the available methods for the discipline of reasons which make the institutions listen to them.

\subsection{Rationality gap}

For all its virtues, collective rationality creates a problem for democratic polities - too often it frustrates the individual wills of the many. Certainly, appeals to reason to constrain popular passion have been justified by a constellation of thinkers like Rousseau, Condorcet, Burke, Madison and even Polybius; indeed, almost all cannons of democracy seek to constrain popular will for the sake of the common good, human rights, principles of justice, etc. ${ }^{22}$ Yet, even while doing so, none of them abandons the notion that authoritative decisions are in some ways responsive to the will of citizens. They could do that on the implicit assumption that by constraining factionalism or populist passions the 'true' will of the people will reign; in one way or another, the collective will has been equated to collective reason. But having recognised that there is a dilemma between the two, this is no longer plausible.

Thus far, the dilemma has been discussed in the literature as a choice between two alternative decisional procedures, but it bears on the very nature of political authority. It is a choice between submitting to acts of collective reason opposed by almost everyone and adopting arbitrary acts, which, even if supported by overwhelming majorities, are not premised on reasons which are themselves supported by such majorities (ie for the majority of people they are not reasons at all). ${ }^{23}$ As we saw in the opening section, there are good reasons to prefer reason to will if we cannot have both, yet if we abandon the pursuit of responsiveness altogether, we are bound to face a considerable problem which I shall call the rationality gap.

It may be argued that the outcome of collective reasoning is the common will. But such a redefinition of the concept would be of little help, as the actual divergence of the collective decision from the individual wills of the members of that collective would lead to their frustration. When

\footnotetext{
22 For a subtle account of this contradiction in the American context, see Joseph M Bessette, 'Deliberative Democracy: The Majority Principle in Republican Government' in Robert A Goldwin and William A Schambra (eds), How Democratic is the Constitution? (AEI 1980).

${ }^{23}$ This may seem to suggest the impossibility of a republican polity; indeed, Kornhauser and Sager conclude that the dilemma shows that collective rationality cannot be guaranteed. See Kornhauser and Sager (n 7) 252ff. But in my view, as every polity displays at least some integrity, it is a special virtue of civic republicanism that it exposes a problem that is not visible from other perspectives.
} 
frustrated individual wills amount to a majority, we have a yawning gap which may threaten the very existence of the collective. Pettit acknowledges that some degree of conformity with popular will is necessary for the collective to exist as an agent at all. In their latest book on the subject, List and Pettit make clear that group agents exist only by virtue of the respective intents of their members. ${ }^{24}$ Certainly, the will to act collectively as a purposive agent in principle is distinct from the disposition that the agent should act in a particular way; nevertheless, one may wonder whether the frustration of members with regard to the latter will not gradually erode their support for the former. Indeed, if on one hand the attitudes of the group agent differ from those of the members, and on the other if the group agent exists solely by virtue of certain attitudes of the members, this would be quite an unstable entity which may necessitate some deliberate maintenance efforts. In any existing collective agent, a varying degree of trust, solidarity and the like can be ascertained amongst members and this can explain their tolerance of recurring rationality gaps. But it is plausible to assume that these are finite, and therefore persistent rationality gaps threaten to deplete them while the conformity of group decisions to individual preferences may replenish them. Therefore, it is incumbent on the republican theory to offer the responsible decision-makers a way to go along this spiral upwards. Thus, nothing in my argument is intended to deny the priority of collective reason claimed by the civic republicans; my aim is only to draw attention to the importance of the rationality gap and the impending necessity for it to be closed. Any viable republican democracy would need to make a constant effort to align collective reason with the majority will. My suggestion is that the grim choice between frustration and populism can be avoided only if we do not have to take members' attitudes to be constant, and the theory of deliberative democracy allows for some optimism with its promise that individual attitudes might be changed in the process. ${ }^{25}$

It should be clear that the rationality gap cannot be bridged by the mere design of the institutions because the opposing majorities against many of the collectively rational decisions will accrue spontaneously outside these institutions anyway. In the real world, both PWM and CWM decision-making happens all the time. When we opt for integrity and gear the constitutions accordingly, the contravening individual attitudes

\footnotetext{
24 List and Pettit (n 6).

25 Dryzek and List had already suggested (in different circumstances) that by deliberation which precedes the aggregation procedure some of the impossibilities can be avoided, and therefore deliberation is a necessary complement to any mechanisms for social choice. See John S Dryzek and Christian List, 'Social Choice Theory and Deliberative Democracy: A Reconciliation' (2003) 33 British Journal of Political Science 1. Below I will show how expost communication may close the gap, and will claim more generally that the gap is closed by a step-wise process of communication in the public sphere.
} 
towards the conclusion will be formed simultaneously, even if no conclusion-wise decisions are taken anywhere at all.

The conflict between collective reason and popular will provides us with a new perspective of the notorious democratic deficit of the EU. The latter is commonly attributed to the depoliticisation of the EU institutions or their alienation from the citizens, but if my argument is correct, this is not caused by depoliticisation per se, but by the rationalisation that is achieved, inter alia, by depoliticisation. Now, this is a sweeping claim and in the next section I will discuss why in many actual cases the problem may not be so acute. Several factors may mitigate (and ideally close) the rationality gap, but when they are inadequate or missing the gap becomes visible and threatens the legitimacy of the authorities.

\subsection{Closing the gap}

The obvious way to close the rationality gap is by appealing to collective identity or bonds of solidarity. ${ }^{26}$ It is commonly asserted that some sense of solidarity is necessary for the outvoted minority to concede to the decision of the majority, and the same may help a frustrated majority to concede to the contravening collective reason. ${ }^{27}$ This sense is a separate reason for citizens to endorse the outcome of the PWM decisions of their community or their government, even when, following their own beliefs on the substance, they would have chosen the opposite. ${ }^{28}$ More interestingly, the decision reached collectively may persuade the group members to change their minds. ${ }^{29}$

Consider, for example, a family deciding whether to buy a car. The family has three members (eg two parents and one sufficiently mature child) and the relevant premises are $P_{1}$ - whether the car is needed by the

${ }^{26}$ Compare with Pettit, who notes that the identification [of group members] with one another will support a wish to reach agreement' on an 'antecedently agreed set of considerations on the basis of which to justify particular judgements'. See Philip Pettit, 'Collective Persons and Powers' (2002) 8 Legal Theory 443, 448.

27 Note that although collective reasoning may create frustrated majorities, this is not always a graver problem than the one with outvoted minorities. As Renaud Dehousse noted, a strict majoritarian rule may feed up centrifugal forces, while collective reasoning avoids the divisions between winners and losers. See Renaud Dehousse, 'Beyond Representative Democracy: Constitutionalism in a Polycentric Polity' in JHH Weiler and Marlene Wind (eds), European Constitutionalism Beyond the State (CUP 2003).

${ }^{28}$ I prefer to speak about identity rather than solidarity or community, as in the case of the rationality gap the controversy is not between majority and minority but between individual and collective conclusions. The controversy is relieved when the individual has some sense that he or she is part of the same (idem) collective entity, and so the decisions are and ought to be identical.

29 This phenomenon has been well discussed. See, for example, Cass R Sunstein, 'The Law of Group Polarization' (2002) 10 Journal of Political Philosophy 175. He notes that in cases where the group matters for its members, 'once they hear what others believe, they adjust their positions in the direction of the dominant position' ibid 179. 
family, $\mathrm{P}_{2}$ - whether the purchase is economically wise, and $\mathrm{P}_{3}$ - whether the increase of the carbon footprint of the family is tolerable. Let the beliefs be distributed according to the following Matrix 2:

$\begin{array}{ccccc}\begin{array}{c}\text { Family } \\ \text { members }\end{array} & \begin{array}{c}\mathrm{P}_{1} \text { : Car } \\ \text { necessary? }\end{array} & \begin{array}{c}\mathrm{P}_{2}: \text { Car } \\ \text { affordable? }\end{array} & \begin{array}{c}\mathrm{P}_{3} \text { : Carbon } \\ \text { footprint } \\ \text { acceptable? }\end{array} & \begin{array}{c}\text { Individual } \\ \text { conclusions: }\end{array} \\ \mathrm{A} & \text { Yes } & \text { Yes } & \text { No } & \text { No } \\ \mathrm{B} & \text { Yes } & \text { No } & \text { Yes } & \text { No } \\ \text { C } & \text { No } & \text { Yes } & \text { Yes } & \text { No } \\ \begin{array}{c}\text { Collective } \\ \text { beliefs }\end{array} & \text { Yes } & \text { Yes } & \text { Yes } & ?\end{array}$

Again there are apparent majorities supporting each relevant premise. A family which is collectivising reason would decide on each premise and then, following modus ponens, would have to buy the car even though the individual will of each member is against the purchase. However, unlike the panel members in the earlier example, here each member of the family is genuinely committed to treating the car purchase as 'our decision.' Therefore, he or she may be inclined to revise his or her beliefs on the premises. C may just figure out new uses for the car and change his or her position on $\mathrm{P}_{1}$. B may still believe it is too expensive, but may start to consider it a well-deserved reward. After seeing the happiness the purchase might bring to the family, A may also relax his environmentalist zeal.

Similarly, in large groups where citizens identify with their group, they will often be prompted by the common opinion shared by their nation to revise their initial individual beliefs about the premises (or at least reconsider the relevance and the weight of some premises, as well as the evaluation thresholds). In other words, the identity-induced endorsement of a certain conclusion will lead them to practise modus tollens and eventually align their beliefs with the conclusions. ${ }^{30}$ I would suggest that the proper role of the elected representatives is precisely to facilitate such alignment. ${ }^{31}$ Ideally, while the community practises modus ponens, the

\footnotetext{
30 This process should be conceived as the social equivalent to the restoration of coherence in the individual mind in the face of the contradictions described by Daniel Kahneman, Thinking, Fast and Slow (Farrar, Straus and Giroux 2011).

${ }_{31}$ As John Parkinson aptly put it in the context of micro-publics, 'Representatives are transmitters of information and instructions in two directions, not just one: ideally they convey the views of their principals, and they convey the arguments of the other delegates back to those principals for further consideration'. See John Parkinson, Deliberating in the Real World: Problems of Legitimacy in Deliberative Democracy (OUP 2006) 32. Habermas assigns the same responsibility to the members of the European Council and this has been observed to be the case with the members of COREPER, see below.
} 
individuals may practise modus tollens. ${ }^{32}$ The most telling example of the latter is the British people's overall opposition to the Iraqi war of 2003, which within a week changed to overall support, once the decision of their government became final (ie the war had started). Apparently, it is the members' own willingness to revise their initial beliefs which is crucial for the rationality gap to close, so that PWM and CWM decisions become identical. Note, however, that there are two related but distinct prerequisites for such alignment - some identification with the relevant group, so that the individuals are willing to reconsider the premises in light of the collectively reasonable decision and the communication of that decision back to them. While lots of ink has been spilled on the former, the latter has gained adequate attention only with the recent interest in the justification of authoritative decisions vis-à-vis the public. ${ }^{33}$ In my view, the latter is no less important, and in the third part of this article I will argue that the problems of the EU lie in the inadequacy of communication, and not of identification.

Conceptually we can distinguish two phases of decision-making: first, a collective decision is reached, and then the members who internalise it revise their initial beliefs. In practice, the phases will not be discrete, but the collective position will be formed and the beliefs revised in a continuous and incremental process of communication which goes both ways. Thus, ideally, all parties would reflectively change their beliefs and preferences during the rounds of deliberation ${ }^{34}$ in response to the arguments of the others and possibly new evidence gathered during the process. ${ }^{35}$ When this process is successful, the decisions reached would be collectively rational and supported by most of the members. This is how, without any mysticism, the Rousseauian general will of the nation is formulated, as an instrument to attain what is perceived as the national interest. On the suggested account, both collective reason and common interest are co-produced through deliberation in the public

\footnotetext{
32 Modus ponens is the inference rule where premises dictate the conclusion, while in modus tollens the conclusion is kept, but some of the premises are revised to restore integrity. See Pettit (n 2) 277.

33 Jurgen Neyer, 'Justice, Not Democracy: Legitimacy in the European Union' (2010) 48 Journal of Common Market Studies 903.

34 Cf Benhabib's democratic iterations. Seyla Benhabib, 'Reclaiming Universalism: Negotiating Republican Self-Determination and Cosmopolitan Norms' (The Tanner Lectures on Human Values, University of California at Berkeley, 15-19 March 2004).

35 Following List and others, by deliberation I mean public discussion which is substantive, balanced and civil. Christian List and others, 'Deliberation, Single-Peakedness, and the Possibility of Meaningful Democracy: Evidence from Deliberative Polls' (2013) 75 The Journal of Politics 80, 83. This is a 'moderately thin' definition, and does not presuppose any shared identity, bonds of solidarity or sense of common destiny, as the more popular conceptions do. Deliberation in this sense is not meant to bring about any degree of consensus; yet it is expected to result in more considered preferences, ibid.
} 
sphere. ${ }^{36}$ Certainly not all national opinions are the result of deliberative exchanges, and in many cases much less plausible mechanisms come into play. The suggestion I make is that while democratic authorities are adopting collectively rational decisions, justified with democratically persuasive reasons as they ought to be, they may persuade the citizens to internalise their decision. The source of this optimism is not only the Habermasian discourse ethics, but also evidence from recent moral psychology which shows that humans have a remarkable capacity to adjust their judgments to be consistent with the opinions supported by the groups they happen to participate in. ${ }^{37}$ More pertinently, evidence from experiments with deliberative polls supports this suggestion, too. ${ }^{38} \mathrm{Sum}-$ marising the results from decade-long research, List and others conclude that even though deliberation hardly brings about any agreement, it does transform the preferences of the participants. ${ }^{39}$ In the second part below, I will discuss examples of collective reason cum belief reversal in EU governance.

In this part, I have discussed the dilemma arising when collective decisions premised on reasons have to be taken, how it ought to be resolved, and the problem that the preferred solution creates. It has also been suggested that reason is collectivised by public contestation, that all contemporary polities collectivise reason and achieve at least some degree of integrity, and therefore they must all face this problem. Finally, it has been suggested that the problem may be mitigated by deliberation in the public sphere. In the light of this account, now I shall turn to the EU as a polity which collectivises reason and faces the associated problem, which in this case is known as the democratic deficit.

\section{The EU as a collectively rational agent}

In this part I shall discuss the EU in light of the suggested perspective. Although Pettit himself does not discuss the EU, ${ }^{40}$ it appears to be

\footnotetext{
36 Certainly, this claim is based on Jürgen Habermas, The Structural Transformation of the Public Sphere: An Inquiry into a Category of Bourgeois Society (MIT Press 1991). Most recently, Habermas has reiterated that 'only an effective and broad based democratic dispute over a common European future could lead to plausible political decisions that would in turn make an impression on the financial markets'. See Jürgen Habermas, 'Bringing the Integration of Citizens into Line with the Integration of States' (2012) 18 European Law Journal 485.

37 See most recently Jonathan Haidt, The Righteous Mind: Why Good People are Divided by Politics and Religion (Allen Lane 2012).

38 List and others (n 35).

39 Note that they also confirm that deliberation does not work by citizens taking cues and adopting ready-made preferences held by the elites. Instead, their post-deliberative preferences are informed by the arguments of the others about their circumstances, beliefs, etc (which is not to say that they do not weigh the considerations of the others differently) ibid 89.

40 The only piece in which Pettit discussed the EU is a short conference comment: Philip
} 
a good test case for civic republicanism. Clearly, the EU is not a system for the expression and aggregation of the will either of its Member States or of its citizens. It is not responsive to either, and it is intentionally designed not to be. On the other hand, it seems to be a highly rationalised decision-maker, and prima facie exhibits agential capacities - it is able to formulate goals and adopt policies which are instrumental to their achievement. Now I will briefly discuss some of its idiosyncratic features to show how they enable collective reasoning (in the broad sense of integrity). In my view, these features make more sense if they are perceived as tools for collectively rational (as opposed to responsive) decision-making. This is necessarily sketchy and will rely entirely on well-known conclusions in the existing literature. I admit to have deliberately cherry-picked the features which work well on the suggested account, but this is warranted by the scope of the claim I make. I do not claim that the EU is collectivising reason all the time - when and to what extent it does is an empirical question. What I claim is that the Union, and its deficit, are better understood through the conceptual lens of civic republicanism. ${ }^{41}$

\subsection{The EU as a purposive community}

The first question is whether the EU is a group which is appropriate to personify in the specified sense. On all accounts, it seems that it is. Whatever the citizens' stance on integration, even the most severe sceptics seem to expect the Union to act rationally in pursuance of certain purposes and to speak in a single voice; they expect it to act as an agent.

Pettit, 'Comment on Walker: Europe's Constitutional Momentum' (2005) 3 International Journal of Constitutional Law 239 which does not address this issue. Yet he has proposed civic republicanism as a general paradigm for international administration. See Philip Pettit, 'Legitimate International Institutions: A Neo-republican Perspective' in John Tasioulas and Samantha Besson (eds), The Philosophy of International Law (OUP 2010). Richard Bellamy systematically applies the republican perspective to the EU with compelling arguments. See eg Richard Bellamy and Dario Castiglione, 'Democracy, Sovereignty and the Constitution of the European Union: The Republican Alternative to Liberalism' in Zenon Bankowski and Andrew Scott (eds), The European Union and its Order: The Legal Theory of European Integration (vol 61, Blackwell 2000). However Bellamy's approach is quite different from the one I have adopted following Pettit, most notably he is critical of depoliticisation which is characteristic both of Pettit's republicanism and EU constitutionalism. See Richard Bellamy, 'Democracy Without Democracy? Can the EU's Democratic "Outputs" Be Separated from the Democratic "Inputs" Provided by Competitive Parties and Majority Rule?' (2010) 17 Journal of European Public Policy 2.

41 Bellamy and his collaborators have already shown that liberal democracy is an inadequate account for the $\mathrm{EU}$, and that civic republicanism (or democratic liberalism in their parlance) is the most appropriate one for a multilevel polity. See Bellamy and Castiglione (n 40) and Richard Bellamy and Claudia Attucci, 'Normative Theory and the EU: Between Contract and Community' in Antje Wiener and Thomas Diez (eds), European Integration Theory (2nd edn, OUP 2009). My argument is somewhat different - that the rationalisation of the EU makes the republican account the most appropriate, and this would be valid even if it was not a multilevel one. The two arguments are complementary but not dependent on each other. 
Still, some scholars deny that the Union has any common purpose ${ }^{42}$ and claim that it is merely a system for the facilitation of international cooperation, enabling the Member States to achieve their goals. However, this understanding is increasingly losing support in positive law. Although the more ambitious precepts of the Constitution were abandoned, the Treaty on European Union (TEU) still ascribes to it as a single body certain purposes ${ }^{43}$ and notably obliges its members to help achieve them. ${ }^{44}$ Apparently, it is treated as an entity capable of having its own goals distinct from those of the members. Further, the Treaty on the Functioning of the EU (TFEU) stipulates that '[t]he Union shall ensure consistency between its policies and activities, taking all of its objectives into account'. ${ }^{45}$ This is perhaps the clearest requirement for a system to collectivise reason that one can find in a legal instrument. There is no need to elaborate further on the numerous cases where secondary law ascribes distinct purposes to the Union to assert that it is appropriate to conceive it as a system for collective agency whose institutions are required to exhibit integrity in their reasoning. ${ }^{46}$

Certainly the EU institutions do not follow the PWM model procedure, but it can be shown that it collectivises reason in the broader sense of displaying integrity. In the remainder of this part, I show that the various EU institutions can be interpreted as the means to achieve integrity and to collectivise reason at the pan-European level. Note that by employing the principle of integrity, the republican account not only legitimises the EU, but also provides a standard for its evaluation. It is commonly asserted that the Union should not be evaluated by the same

\footnotetext{
${ }^{42}$ For example, Eleftheriadis vehemently objected to the claims of Joshka Fischer and Jurgen Habermas ascribing common purpose to the Union; however, he would probably not object to ascribing a purpose in the practical terms used here. See Pavlos Eleftheriadis, 'Cosmopolitan Law' (2003) 9 European Law Journal 241; and more recently Pavlos Eleftheriadis, 'The Moral Distinctiveness of the European Union' (2011) 9 International Journal of Constitutional Law 695.

${ }^{43}$ Art 3 TEU stipulates that the aim of the EU is to promote peace, its values (listed in art 2) and 'the well-being of its peoples'. It elaborates further that the EU has to establish an area of freedom, security and justice; an internal market, etc. See OJ C 83/17.

44 Art 4 (3) TEU stipulates that The Member States shall facilitate the achievement of the Union's tasks and refrain from any measure which could jeopardise the attainment of the Union's objectives' ibid.

45 Art 7 TFEU, OJ C 83/53.

46 Once again, this notion of purposive community should be understood pragmatically; I hasten to distinguish myself from the grand narratives of a common European destiny, eg Joschka Fischer, 'From Confederacy to Federation: Thoughts on the Finality of European Integration' (Speech at the Humboldt University in Berlin, 12 May 2000). For a pertinent criticism of such narratives, see Justine Lacroix, 'Does Europe Need Common Values? Habermas vs Habermas' (2009) 8 European Journal of Political Theory 141. It seems to me that Lacroix's notions of constitutional discipline and shared critical reflections are not unlike the public contestations espoused by republicanism.
} 
standards as nation-states because it is a polity of its own kind, ${ }^{47}$ but this allows it to be its own standard, which is normatively implausible. ${ }^{48}$ The suggested account avoids this problem because while absolving the EU from the need to be responsive, it subjects it to the principle of integrity which can be quite demanding if taken seriously.

\subsection{Rationalising the Union}

It is well known that the European Coal and Steel Community (ECSC) was created on the Madisonian rationale to prevent the excesses of the wills of European peoples in certain areas which had resulted in suicidal trade protectionism and two world wars. ${ }^{49}$ Economic liberals today would claim that the Union is the embodiment of economic rationality which is necessary to constrain the populist immoderation of the welfare state, ${ }^{50}$ and many social democrats would almost agree with that, by decrying the crude market rationality of the EU which constrains the wilful policies of national democracies. ${ }^{51}$ A stark recent illustration of its function to discipline unreasonable national governments came in the autumn of 2011 when two national governments were effectively fired by their European peers for failing to act according to the imperatives of fiscal reasonableness.

While the latter examples may be exceptional and while they certainly created considerable controversy, this situation was quite common during the process of accession of the new Eastern democracies. Termed 'conditionality' in that context, it was celebrated as a tool of EU foreign policy to transform the candidate countries into rationalised Union Members. ${ }^{52}$ The special monitoring to which Bulgaria and Romania were sub-

\footnotetext{
${ }_{47}$ Most prominently, Giandomenico Majone, "Europe's "Democratic Deficit": The Question of Standards' (1998) 4 European Law Journal 5. Interestingly, the author asserts that this is so because of the unique goals the EU has to pursue.

48 Francis Cheneval and Frank Schimmelfennig, 'The Case for Demoicracy in the EU' (Paper prepared for the EUSA Conference, Boston, March 2011).

49 A brief look in any textbook on the EU will inevitably show a paragraph about the postwar distrust of national governments. See, for example, Paul P Craig and Gráinne De Búrca, EU Law: Text, Cases, and Materials (4th edn, OUP 2008) 2: 'discrete economic sectors [to] be managed efficiently and technocratically by supranational institutions away from the fray of politics'. It is ironic that the Community was created because of the distrust of national governments. The Union delivered on its promise while helping the national governments to deliver on theirs and thus regain trust. Now, the EU is increasingly distrusted because it is a constraint of the re-credited national governments.

50 For example, Majone observed that by Community regulation 'industries want to avoid inconsistent and progressively more stringent regulations' in the Member States. See Giandomenico Majone, 'The EC: An "Independent Fourth Branch of Government"?' (1993) EUI Working Paper SPS 93/9, 19.

51 See, for example, the discussion in Fritz Scharpf, 'Economic Integration, Democracy and the Welfare State' (1997) 4 Journal of European Public Policy 18.

52 With regard to the countries from the Western Balkans, the (failing) building of nation-
} 
jected (in the area of justice and home affairs!) even after their accession is another case in point. ${ }^{53}$ Also, the EU is commonly used as a contestatory mechanism vis-à-vis the policies of the Member States by their citizens as well. In particular, national civic actors, frustrated in the national political process, contest domestic legislation either directly by complaints to the European Commission, or indirectly by asking national courts to apply the acquis in the face of contravening national law. The latter examples are not of the rationalisation of European decision-making, but of the national one by the European institutions, yet they are still cases in point, where certain discipline is imposed on popular will to maintain the integrity of the European purposive community. ${ }^{54}$ The forthcoming fiscal and banking union would extend this type of European disciplining of national will to the old and great Member States as well.

The rationalisation was and still is achieved by mechanisms for depoliticisation and contestation. Although the framers by no means lacked bold visions for 'ever closer union', what they seemed to care most about was to design a depoliticised bureaucracy able to deliver decisions as rational means to the stipulated Community ends. The ECSC established a surprisingly powerful supranational institution - the High Authority - to govern the two strategic industries of the Member States on the basis of the common premises enshrined in an international treaty. ${ }^{55}$ This method has continued until today, and the EU is crammed with all the types of contestatory institutions that Pettit enlists - constitutional courts, consultative bodies and arms-length appointments. His call to reduce the hands-on power of elected politicians neatly corresponds to Majone's assertion that the European governments delegated powers to the

states was explicitly contrasted to the building of Member States. See Giulianno Amatto and others, 'The Balkans in Europe's Future' (Report of the International Commission on the Balkans, Centre for Liberal Strategies 2005).

53 On the occasion of democratic reason yielding to populism in Hungary, Romania and Bulgaria, Jan-Werner Mueller recently wrote for the press: 'One of the explicit goals of European enlargement to the east was to consolidate liberal democracies .... Governments in turn sought to lock themselves into Europe so as to prevent backsliding; it was like Ulysses binding himself to the mast in order to resist the siren songs of illiberal and anti-democratic demagogues in the future'. See Jan-Werner Mueller, 'Europe's Democracy Dilemma: How and When to Step In?' The Guardian (London, 19 July 2012). This EU-enforced rationalisation is considered by many to be a blessing in the concerned Member States, for it compensates for the inadequate rationalisation of domestic policy by the populist governments.

54 See Menon and Weatherill who also make the argument that the EU is to overcome the democratic failures of the Member States. Anand Menon and Stephen Weatherill, 'Transnational Legitimacy in a Globalising World: How the European Union Rescues its States' (2008) 31 West European Politics 397.

55 The Schuman Declaration famously proposed that 'Franco-German production of coal and steel as a whole be placed under a common High Authority .... The setting up of this powerful productive unit, open to all countries willing to take part and bound ultimately to provide all the member countries with the basic elements of industrial production on the same terms, will lay a true foundation for their economic unification'. 
EU in order to insulate certain policies from majoritarian government and to 'produce a supranational regulatory regime which not only complements, but is ... more credible than the national systems'. ${ }^{56}$ Today, the view that the EU as a whole is only a system for rational constraint of the will of the Member States is difficult to sustain in the face of its growing competences to make political choices. ${ }^{57}$ Notwithstanding this, the constitutional structure of the Union remains essentially one of a contestatory system for collectivising reason. ${ }^{58}$ While the particularities of the EU are still easily explainable in classical functionalist terms, I believe republicanism takes us further, because functionalist explanations best suit the 'regulatory' and 'technical issues', and are not well suited to apparent political choices, a limitation which in my view republicanism does not have. ${ }^{59}$

The most pertinent example of a mechanism geared towards the integrity of collective decision is the 'Community Method' by which most of the legislation is adopted - upon the proposal of the Commission by the European Parliament and the Council acting together. The Commission's primary function is to make expert policy proposals furthering the otherwise unrepresented community interest, so much so that it has been likened to an independent think-tank. ${ }^{60}$ In practice, the Commission may promote a certain parochial interest, but only inasmuch as it is rationalised, ie presented as the best way to attain a common pan-European good. When such a proposal is made, it is subjected to contestations from all sides - Member States (in the Council), factions (in the European Parliament), and regional and sectoral interests (in the Committee of the Regions and in the Economic and Social Com-

56 Giandomenico Majone, 'Independence Versus Accountability? Non-Majoritarian Institutions and Democratic Government in Europe' [1995] The European Yearbook of Comparative Government and Public Administration 117, 125.

57 Majone himself recently argued that political decisions should be taken by political process, although he maintains his distinction between political and regulatory issues. See Giandomenico Majone, Dilemmas of European Integration: The Ambiguities and Pitfalls of Integration by Stealth (OUP 2009).

58 There have been numerous calls from various quarters for politicisation of the EU. See Bellamy (n 40) and also Andreas Follesdal and Simon Hix, 'Why There is a Democratic Deficit in the EU: A Response to Majone and Moravcsik' (2006) 44 Journal of Common Market Studies 533. Note that politicisation is not always inimical to rationalisation. Follesdal and Hix claim that 'electoral contests provide incentives for the elites to develop rival policy ideas' (ibid) which may be a route to avoid what Pettit calls false negatives.

59 Reason can be and ought to be collectivised on distributive decisions as well. Although my example in the beginning of the paper was on 'regulatory' issues, it can be applied to distributive ones - one can think of the Greek bailout where the premises are 'default imminent', 'help deserved', 'austerity measures working', etc. Indeed, any decision which must be justified with several separate reasons creates a dilemma and the associated rationality gap.

60 John Temple Lang, 'The Commission: The Key to the Constitutional Treaty for Europe' (2003) 26 Fordham International Law Journal 102. 
mittee respectively). More importantly, Member States in the Council tend to accept it (because of the rationality-driven momentum behind the proposal) or must provide rational argumentation in order to publicly reject it. This contestatory mechanism is protected by a prohibition for the Member States to initiate their own proposals (in most areas), thus barring their parochial interests from the agenda. On the republican account suggested here, the Commission, as the only repository of knowledge of the pan-European good, is responsible for avoiding false negatives, ie 'failures to perceive options that public valuations would support'. ${ }^{61}$ The Member States in the Council are responsible to avoid false positives, ie from one side to prevent the Commission from promoting sectional interests as common ones, and from the other to prevent the disproportional burdening of their own interests. This is actually a mirror image of Pettit's model: he suggests that the elected institutions should be constrained by expert bodies, ${ }^{62}$ while with the Community method the expert proposals are constrained by political actors. Either way, the effect should be similar. The Community method may well go a bit further in the avoidance of false positives through the restriction of the legislative incentive of the political actors. It is worth emphasising that the Commission has no power to force acceptance of its proposal other than the persuasiveness of the reasons given in support. Its draft must be so rationalised that it would be impossible for (almost) any of the political representatives to reject it publicly. For better or worse, the Community method is the most striking example of collectivised reason displacing (even if not overcoming!) the popular will. ${ }^{63}$

In cases where the authority of the EU institutions to regulate by hard law is limited, 'soft' alternatives have become increasingly common and their claim for legitimacy is commonly supported by claims for effectiveness and credibility. ${ }^{64}$ Under the umbrella term New Modes of Governance (NMG), a great variety of practices and structures has developed, such as policy coordination, peer review, monitoring and comparative analysis, operating in a heterarchical network involving public and private bodies, as well as independent scientific authorities. Characteristically, decision-making in that mode is partly or completely outside

\footnotetext{
61 Pettit (n 18) 60.

62 ibid.

63 Note also that for Majone the Commission is a fiduciary representative of pan-European interest, which again corresponds to Pettit's concept of indicative representation, even though they have different reasons to arrive at these views. See Majone (n 57) and Pettit (n 19).

64 See Richard Bellamy and others 'Evaluating Trustworthiness, Representation and Political Accountability in New Modes of Governance' in A Heritier and M Rhodes (eds), New Modes of Governance in Europe: Governing in the Shadow of Hierarchy (Palgrave Macmillan 2011) 2 .
} 
the control of the traditional forms of authority, and generally presupposes cooperative rather than legally binding relationships. ${ }^{65}$

Again, the NMGs are not at ease in the liberal paradigm, but they sit well on the suggested account with its focus on reasons and justification. Indeed, the participation of unelected experts or stakeholders, a 'selectorate' as it were, is problematic on the classical accounts where counting votes is what matters. But they should be welcome if their contribution to decision-making is seen in terms of rationalisation - they ask for the reasons for choices, contest them on substantive grounds, and offer alternatives. As they have no formal powers, for their claims to have any chance of success they must substantiate them with arguments and evidence which the power players cannot easily ignore in public. I have already mentioned the critical role of organised civic society in public contestations. Thus, on the one hand, the methods of new governance, such as direct participation, expert reports, comparative examples, etc, rationalise the traditional hierarchical decision-making. On the other, the NMGs are widely used in the EU to actively make policies, coordinate, and set goals; the participants share information, exchange arguments and counterarguments and generally justify their claims with reasons which can pass muster in the public discourse. ${ }^{66}$ As alternatives or complements, in both the Community Method and the NMG, the role of reasons is central for the decision-making, therefore driving it towards collectivising reason, premise-wise.

Certainly, not all decisions are taken through either of these alternative avenues, and in several important domains the political will (formed at national level) dominates. The Union is only partly rationalised, and this is precisely in the areas where there are robust commitments to common purposes. So where these commitments are thin or absent, the Union is merely aggregating the wills of the Member States. For example, in the domain of foreign policy, even after the Lisbon Treaty, no common purpose has been stated, except in very general terms, and that is why it is not appropriate for the EU to seek to behave as an agent at all. The common criticisms for its failing to act coherently in this area are equally inappropriate. Instead of rationalisation via the Community method, the

\footnotetext{
65 It is debatable whether the new modes of governance are a radical alternative to the 'old' one, as Sabel and Zeitlin believe, or whether they are the two ends of a continuum, as Tania Borzel maintains. For a discussion of the contested interpretations of the various modes, see Kenneth A Armstrong, The Character of EU Law and Governance: From "Community Method" to New Modes of Governance' (2011) 64 Current Legal Problems 179.

66 In a seminal paper, Scott and Trubek emphasised the centrality of deliberation, which serves 'both to improve problem-solving capabilities and possibly provide some degree of democratic legitimation'. See Joanne Scott and David M Trubek, 'Mind the Gap: Law and New Approaches to Governance in the European Union' (2002) 8 European Law Journal 1, 6.
} 
Union acts on an ad hoc basis only when there is political will among the Member States aggregated in a conclusion-wise mode. ${ }^{67}$

Beyond their role as participants in governance, old and new, citizens have another way to become involved in decision-making which similarly drives the Union towards collectivised reasoning. They are empowered to contest European legislation in the European Court of Justice (ECJ) which has made the latter quite unlike the other international courts. ${ }^{68}$ Again this is rationalisation, here in the form of judicialisation, which makes the premises, not the conclusions, pivotal for the final decision. Thus, the four freedoms were constitutionalised by the ECJ in the 60s, without anyone noticing that constitutionalisation happens to be the first mechanism that Pettit mentions in his model of republican polity. ${ }^{69}$

Another contestatory mechanism (which so far has failed to deliver on its promise) can be seen in the coveted involvement of national parliaments in the public valuation of Union legislation. Within the Member States, the national parliaments occupy the focal point of collective reason. ${ }^{70}$ At the EU, the European Parliament (EP) is supposed to be such an institution, but while the pan-European public sphere is barely emergent $^{71}$ it cannot be the focus and catalyst of opinion formation. The gradual increase in its formal powers is no immediate remedy for this situation because there is no connection between the growing democratic politics inside the European Parliament and EU Council and the views of the public'. ${ }^{72}$ Note, however, that this does not prevent the EP from providing an important avenue for the public actors to contest legislative proposals. ${ }^{73}$ Even if the debates within have little repercussion on the general public outside, in recent years interested observers have witnessed many vibrant contestations, and occasionally the citizens or stakeholders have prevailed in the arguments, securing the amendment or defeat of Commission proposals. ${ }^{74}$

\footnotetext{
67 This is oversimplified, and even the decisions in foreign and defence policy are influenced by certain considerations and reason giving, especially in the field of human rights. Still, the point is that in some areas the rationalisation has gone much farther than in others.

68 Even as the access of citizens to the ECJ is still severely limited by the Plaumann doctrine (Case C 25/62 Plaumann v Commission [1963] ECR 199).

69 Pettit (n 18).

70 See Habermas (n 36). Note that even though in contemporary democracy parliaments are rarely policy makers, they remain the central legislative arenas. See Nelson Polsby, 'Legislatures' [1975] in Philip Norton (ed), Legislatures (OUP 1990).

71 Thomas Risse, 'An Emerging European Public Sphere? Theoretical Clarifications and Empirical Indicators' (Paper presented to the conference on the 'Europeanisation of Public Spheres, Political Mobilisation, Public Communication and the European Union', Science Center Berlin, 20-22 June 2003).

72 Follesdal and Hix (n 58) 553.

73 I am grateful to an anonymous reviewer for alerting me to this point.

${ }^{74}$ A recent example being the defeat of the Anti-Counterfeiting Trade Agreement (ACTA) in
} 
On the other hand, the national parliaments are deliberately disempowered vis-à-vis the EU so they have been redundant as an avenue for the contestation of EU policies. The Lisbon Treaty introduced the socalled 'yellow card' through which national parliaments are expected to contest draft European legislation, in parallel, and probably before the position of their government is expressed or even formed. While there may be doubts about the actual efficacy of the mechanism, this certainly is yet another contestatory institution for further rationalisation of the EU. In the third part, I shall revisit this; for now, it suffices to say that the involvement of parliaments promises to break the singularity of the national voices of Member States in EU matters and this drives the collectivisation of reasoning up from national to European level.

The process known as comitology is perhaps the European champion of deliberative democrats. It allows the Commission to adopt acts of delegated legislation which are subject to review by special committees consisting of national experts, microcosms of the Councils as they were. Although the procedures vary (and were just reformed pursuant to the Lisbon Treaty), the core principle is that if committee members disapprove of the proposal, it is referred to the Council. In the overwhelming majority of cases it is not, and is in effect approved. Christian Joerges and Jürgen Neyer were perhaps the first to note that the comitology committees represent a novel 'forum for deliberative politics' where the participants are genuinely engaged in the search for the common good. ${ }^{75}$ In a case study of the regulation of foodstuffs they found that:

In comitology, however, preferences cannot be simply asserted, but need to be justified by arguments on health risks which are backed by scientific evidence - a feature which seems astonishing to international relations theorists, but which was confirmed by all delegates ... and which is also supported by our own observations of committee sessions. Thus, relative power would need to be defined with regard to the ability to present and substantiate convincing arguments. ${ }^{76}$

From our perspective, the comitology committees are fora for contestations - in principle the national experts can challenge the Commission proposal, but only if they can justify their claim that it does not pertain

the summer of 2012 as a result of intensive public criticism throughout Europe. This was also a rare case of the successful formation of a pan-European public opinion.

75 Christian Joerges and Jurgen Neyer, 'From Intergovernmental Bargaining to Deliberative Political Processes: The Constitutionalisation of Comitology' (1997) 3 European Law Journal 273.

76 Christian Joerges and Jurgen Neyer, Transforming Strategic Interaction into Deliberative Problem-solving: European Comitology in the Foodstuffs Sector' (1997) 4 Journal of European Public Policy 609. 
to the agreed common purposes. The successful adoption of the proposal supposes that it does, and so comitology appears to be another mechanism to collectivise reason. Further to this, we may assume that the expertise of the committee members changes the focus of the deliberations. Unlike the political leaders in the Council or EP, here the members are competent to discuss the scientific foundation of the policy proposals rather than their overall end. So we can expect that the debate in such committees would focus on the factual premises rather than the policy conclusions, increasing the weight of the former in decision-making at the expense of the latter. ${ }^{77}$ Once again, the decision-making is centred on the premises to drive the system away from CWM and towards the collectivisation of reason.

The picture is similar if we turn to the internal mode of operation of the Council itself or its working groups. ${ }^{78} \mathrm{~A}$ growing body of constructivist scholarship finds abundant empirical evidence that members and staffers in all these bodies act in a non-confrontational, cooperative, 'pro-norm', ${ }^{79}$ consensual and 'deliberative mode'. ${ }^{80}$ They claim that the decision-making is driven to a considerable extent by arguments rather than by bargaining. ${ }^{81}$ In the words of Jeffrey Lewis, in the Council 'the negotiators subject claims to group scrutiny for collective legitimation or

\footnotetext{
77 Certainly, this is only a hypothesis. It would be very interesting to test empirically to what extent comitology committees decide on a premise-wise basis, but unfortunately comitology is notoriously non-transparent and there is little evidence either way. Note that the lack of transparency raises legitimacy issues, but it has no bearing on the claim that comitology shifts the focus from conclusions to premises and collectivises reason in that sense.

78 For a recent overview, see Jeffrey Lewis, 'Council of Ministers and European Council' in Erik Jones and others (eds), Oxford Handbook of the European Union (OUP 2012). See also Jeffrey Lewis, 'How Institutional Environments Facilitate Cooperative Negotiation Styles in EU Decision Making' (2010) 17 Journal of European Public Policy 650, and the other articles in the same issue.

79 When acting in pro-norm mode, the agents may still promote strategic interests, yet they comply with the established conventions for cooperative behaviour and perceive it as their duty to reach an agreement or at least not to appear obstructionist. In such cases, the agents are commonly instructed to 'oppose as long as not isolated'. See the contribution of Jonathan Aus in Daniel Naurin and Helen Wallace (eds), Unveiling the Council of the European Union: Games Governments Play in Brussels (Palgrave Macmillan 2008) 116.

80 Some authors tend to equate deliberation with any non-confrontational mode of decision-making, which is misleading. There is very little public deliberation in the Council or the various committees, and without an existing pan-European public sphere, the EU is short of the ideal of deliberative democracy. To avoid confusion and in line with the definition above (n 35), I am using the term only for deliberation in the public sphere which affects the opinions of the citizens, and shall refer to the rest as cooperation. Notwithstanding this, such practice may still lead to collectively reasonable decisions and this is often achieved presently in the EU.

81 'Arguing' employs assertions for the factual premises of the contested decision, while in 'bargaining' the process focuses on the preferred conclusions. In bargaining, the outcome is usually determined by factors unrelated to the issue itself, while the premises which are relevant are disregarded.
} 
rejection'. ${ }^{82}$ Again this is not to say that the Council decides in PWM - it does not. But the focus on reasons brings about more integrity and collective reason in the broader sense.

Although the witnessed 'deliberative' practices are distinct from the procedure defined above as collective reasoning, they are related to it in at least two ways which are relevant for this paper. The first way is by the central role of the argumentation and reasons in the decision-making of these bodies which seems undisputed. All of the studies support the conclusion that reasons matter, and when they matter systems tend to display integrity even if they do not adopt the decisions by explicit premise-wise voting. The second way is by the constraints on the choices placed on the decision-makers - they have to appear cooperative and mindful of what is understood as collective purpose. Thus, their decision must respect the whole body of previous decisions (including nonbinding ones such as action plans and impact assessments) and can be contested for being incongruent with them. Again, although such a norm-governed mode is not identical to PWM, it can bring about the integrity of decision-making indirectly (as the contestatory mechanisms do according to Pettit). ${ }^{83}$ There are also other features of decision-making in the Council and the like, akin to deliberation, most importantly the evidenced frequency of consensus and persuasion, but they are not relevant for the argument of this paper.

\subsection{Closing the gap in COREPER}

COREPER is another institution where the abundant evidence for the argumentative and consensual mode of decision-making in the empirical literature warrants the conclusion that it is geared to collectivise reason. But it is interesting in another way too. This is the COmmittee of the diplomatic REPresentatives of the Member States to the EU, who in theory are agents of their governments. Apparently, when they reach consensus after deliberations (which they often do) some of them must

82 Jeffrey Lewis, 'Strategic Bargaining, Norms and Deliberation' in Naurin and Wallace (n 79) 173. He notes that the corollary of this is that agents are open to persuasion by good arguments, but the actual change of heart of the opponent is not necessary for my argument, as long as even the unpersuaded agents find it difficult to maintain unsubstantiated positions.

83 It can be demonstrated by an abstract model that when the proposals are screened ex ante for conformity with a certain inference rule or principle, the discursive dilemma is avoided and the adopted decisions are collectively rational. See Gabriella Pigozzi, 'Belief Merging and the Discursive Dilemma: An Argument-based Account to Paradoxes of Judgment Aggregation' (2006) 152 Synthese 258. In republican terms, this would mean that the Council is a contestatory institution where proposals are subjected to criticism and those which are exposed as not conforming to the guiding principles of EU integration are presumably defeated. For a similar abstract model, see also Jesus Zamora Bonilla, 'Optimal Judgment Aggregation' (2007) 74 Philosophy of Science 813. 
have strayed away from the initial instructions received from their principals. Certainly, sometimes they receive new instructions en route but this is not always the case. Jeffrey Lewis observes that that members of COREPER 'have earned some notoriety for being able to find consensus on anything given enough time to "cut slack" and sell results back home's4 and also "[an] observable pattern of deliberation, used regularly by COREPER to find solutions, is the collective plotting to overcome domestic reserves ("cut slack") or force a national capital to rethink instructions'. ${ }^{85}$ Thus, COREPER appears to be not only reaching a cooperative (and presumably collectively rational) solution, but also to engage in ex post advocacy for it. An interviewed member revealed that it is one of their 'standard practices' ${ }^{\prime 86}$ to ask the committee to help them persuade their principals and constituencies at home. ${ }^{87}$ These observations are very significant for the argument of this paper because they suggest that modus tollens is regularly practised in the EU, when the outcome of collective reasoning is internalised by the members of the deliberative bodies just like the family in the car purchase decision model discussed in the first part of this paper. Here, the motives for a change of heart may be less noble than identification with the collective, yet constructivist scholarship has observed that social norms, webs of informal relationships, comity and organisational culture have similar effects. ${ }^{88}$ There are many reasons which may lead the agents to internalise a certain decision and then update their initial premises to align the outcomes of individual and collective reasoning. From this brief glance at the community institutions, it appears that what Joerges and Neyer observed in comitology may be generally applicable to all EU bodies: "the institutionalisation of interaction [is] a process of internalising new preferences and even identities. Institutionalisation ... is a cognitive process that involves a redefinition of the self and the other". ${ }^{89}$ Sceptics may find the redefinition of the self is too demanding, but it may suffice if the participants reconsider only their preferences, and there is considerable evidence that they often do. ${ }^{90}$

Joerges and Neyer further note that 'delegates, perceiving themselves as part of a transnational problem-solving community, may be

84 Lewis (n 82) 170.

85 ibid 174.

86 ibid 174, emphasis added.

87 Similar is the case in many other committees. For another example, see A Niemann, 'Deliberation and Bargaining in the Article 113 Committee and the 1996/97 IGC Representatives Group' in Naurin and Wallace (n 79).

88 Once again, the reader is reminded that for the argument developed in this paper it is irrelevant whether committee members were actually persuaded or had other reasons to embrace the collective decision.

89 Joerges and Neyer (n 75) 291.

90 See the literature referenced in footnotes 37,38 and 39. 
able to change their governments' perceptions of interests or even simply bypass them'. ${ }^{91}$ Apparently, there is a huge difference between changing and bypassing formed national positions. Although integrity may be achieved in both cases, the latter is much less democratically acceptable; furthermore, it will open a rationality gap. However, if members subsequently persuade their principal, the system would be practising modus tollens: representatives would collectivise reason in the deliberative body, and undertake the responsibility to change the beliefs of their governments (and ideally their fellow citizens) on the premises. Thus, the conclusions reached by individual governments will be aligned with the collective conclusion reached in the respective councils of the Union. On the suggested republican understanding, collective reasoning should go in two directions, and therefore the 'agents' are not only allowed, but ought, to be transmitters in both directions - in democratic iterations which may close the rationality gap..$^{92}$ In the same vein, Habermas recently insisted that 'the heads of government would have to reach an agreement ... and campaign for this in their national public arenas'. ${ }^{93}$ So, while traditionally the heads of governments are conceived as agents of their sovereign people, in a surprising twist Habermas allows the relationship to be reversed so that leaders reach agreements at the European level and persuade their national public opinions later.

Once again, none of this is to say that all or even most of the decisions adopted by the EU are collectively rational. While various political scientists give evidence of a considerable degree of deliberation on reasons and argument-based contestations in all institutions, the question whether arguing or bargaining prevails is bound to remain open. ${ }^{94}$ Yet the studies discussed in this part can bear the conclusion that the EU is a system geared to collectivise reasoning by means of depoliticisation and

91 Joerges and Neyer (n 76) 619.

92 Compare again with Parkinson: "the "better arguments" that persuade representatives within a micro-deliberative forum will also convince people outside it once they have been exposed to those arguments in their own, separate deliberations'. See Parkinson (n 31) 32. For an abstract example of how such a feedback loop would work, recall the car purchase example discussed at the beginning of the paper. In the context of the EU, the decision may be to fund the construction of a chemical plant. Once the representatives have reached agreement to support the project, the representative of state A may persuade his government that the plant is sufficiently safe (probably using expert arguments provided by his partners), the representative of state B may persuade her government that it is going to be less costly than expected, and the one of state $\mathrm{C}$ - that the plant is well worth the effort.

${ }^{93}$ Habermas, 'Bringing the Integration of Citizens into Line with the Integration of States' (n 36) 486.

94 Summarising a decade-long research programme carried out by a constellation of political scientists, Deitelhoff and Muller claim that the answer is inconclusive and is bound to remain so. See Nicole Deitelhoff and Harald Müller, 'Theoretical Paradise - Empirically Lost? Arguing with Habermas' (2005) 31 Review of International Studies 167; and also Andreas Warntjen, 'Between Bargaining and Deliberation: Decision-making in the Council of the European Union' (2010) 17 Journal of European Public Policy 665. 
contestation, and thus at least some of the decisions are taken as if in premise-wise mode. On the other side of this coin, the Union appears as a test case for civic republicanism; its idiosyncrasies may be illustrative of the problems that are neglected by the republican theory, ${ }^{95}$ in particular the one I called the rationality gap. If every decision which abides by the integrity requirement potentially opens a rationality gap, the EU, as the most rationalised empirical polity, is bound to experience it most acutely. Not surprisingly, it is the EU and not any nation state which is notorious for its 'democratic deficit'. On the suggested account, the deficit must be understood as the difference between where the previously established premises would lead and where the majority of the Member States (or citizens) would prefer to be. ${ }^{96}$ In other words, this is the gap between what counts as 'our' decision as a Union and 'our' preference as a group of individual members. The sense of alienation and frustration citizens experience is just a symptom of this persistent and systematic difference.

This claim, however, does not conceive the EU simply as an alienated, elitist or bureaucratic organisation which defies the will of its citizens. As was discussed in the first part, the discursive dilemma may arise for any collective body which decides on the basis of some reasons and this is regardless of whether the agents A, B and C in Matrix 1 are representatives, bureaucrats or segments of the population. Depending on the actual distribution of their beliefs, any rationalised polity may experience rationality gaps, even if the actual officials who take the decisions adequately represent the views of the citizens without the impossibilities, distortions or frictions identified by the social choice scholarship. The pervasiveness of the problem illustrated by the abstract model suggests that the question is not why the EU experiences democratic deficit, but rather why the nation-states do not, and I will turn to this in the next part. ${ }^{97}$

95 Pettit and List discuss what they call impossibility results, which are more general than the rationality gap. See List and Pettit (n 3). They suggest how the conditions which lead to such impossibilities can be plausibly relaxed to make the normatively attractive social choice procedure possible. Yet these papers are very abstract and rarely discuss what the suggested functions would look like in the real world.

96 If we take the Member States to stand for the position of their citizens, we can interpret the gap as the difference between the Union decision and the will of its citizens. But it is uncertain whether this is plausible - as the Member States themselves collectivise reason, their position is not identical to their public opinion. On the other hand, in nation-states the two are often aligned by deliberation in the public sphere, as will be discussed below.

97 Certainly this is not to say that the EU does not suffer from numerous institutional pathologies, where the Commission or even obscure advisory agencies may force upon the Member States and citizens decisions which are neither collectively rational nor supported by sufficient majorities. The rationale given for such regimes is the 'objectivity' of expert bureaucracy, but this is itself a contested issue. For a forceful argument against it, see Marjolein BA van Asselt and Ellen Vos, 'The Precautionary Principle and the Uncertainty Paradox' (2006) 9 Journal of Risk Research 313. Compare also Elizabeth Fisher, Risk Regulation and Administrative Constitutionalism (Hart 2007). 
Thus, if I am correct to link the rationality gap with democratic deficit, it follows that the latter is not a matter of institutional design. It is unavoidable for any group which is collectively rational, ie which is able to collectively commit to certain ends and then systematically take the actions which are rational means to achieve them. All constitutional reforms will face the identified impossibility. Rendering the institutions more responsive will make the so far silent popular will explicit and its clash with the collective reason will become even more visible, while still failing to provide a way to resolve the conflict.

The claim that the Union should not be made more responsive to the will of its citizens is counterintuitive and appears to be in tension with my earlier claim that reason is collectivised by public contestations (which commonly include some form of citizen participation). This is because, on the republican account, participation is welcome with regard to the premises but, as the discursive dilemma teaches, may be in tension with the conclusions reached. The normative reasons to centre the decisionmaking on the premises were discussed in the first part; but this shift is also necessary to make citizen participation meaningful. In a democracy, the simple statement of an unrepresentative stakeholder on their preferred conclusion makes little sense without the assertion of certain facts which justify the claim in general terms. Indeed, the participants in any decision-making process would rarely omit supporting their claim 'we want policy $\mathrm{P}$ to be adopted' with a more or less elaborate statement 'because $\mathrm{P}_{1}, \mathrm{P}_{2}$ and $\mathrm{P}_{3}$ obtain'. Thus, citizens involve themselves in the decision-making with a certain desired conclusion in mind, but, to get it adopted, they make arguments and counterarguments on the premises. As a matter of practice, they contest the judgments of the relevant authority on the established premises - using new arguments or providing new information - or point to the relevance of new premises. ${ }^{98}$ If a polity is to collectivise reason, the unfortunate lesson from the discursive dilemma is that the input citizens provide should be on the premises, and so the input per se does not contribute to closing the gap. What may contribute is the communication of the justification back to the citizens.

In this part I have 'portrayed' the EU as a republican polity. This is to say that I have demonstrated that the EU can be conceived in republican terms and that its peculiar institutional system makes more sense if conceived as a way to avoid arbitrary decisions and collectivise reason in

\footnotetext{
98 Thus, the exclusion of a premise which is highly relevant for a certain group from consideration in decision-making renders the decision unjustifiable for that group. For example, the current GMO regime makes human health and safety relevant premises but excludes all concerns for the cost of co-existence with non-GMO crops. As the latter is of paramount concern for organic farmers, any decision which does not take it into account is unjustifiable and arbitrary for them.
} 
that sense. I do not claim, however, that the EU is a republican polity, ie that it satisfies the republican ideals, which is an empirical question and beyond the scope of this paper.

On this understanding, the Union is bound to face a rationality gap, as all polities which collectivise reason do. Recall from the first part that this gap is a structural problem which arises whenever polities collectivise reason. However, even if the problem is ubiquitous and persistent, I have suggested that it may not be an insurmountable one, as sometimes the agents internalise the collective decision and revise their initial beliefs so that the gap is closed. The findings of constructivist scholarship have a very interesting bearing on this intuition. The evidence for persuasion and cooperation in the EU corroborate the one from the deliberative polls (mentioned in the conclusion of part one) that deliberation changes preferences so it can close the rationality gap. Indeed, in Brussels the agents (ministers and bureaucrats) at least sometimes convince each other, change their beliefs and preferences, cooperate, agree, or conform to norms and public expectations. Yet, one may wonder why it is the Union, and not the other polities, which seems to exhibit the most severe democratic deficit? For the deliberation to succeed in closing the gap, there were two enabling conditions that emerged in the first part. The first was the willingness of the citizens to internalise the collective decisions, and the second was the availability of channels for the reasons for these decisions to reach back to them. While the lack of the former is much discussed and lamented, the importance of robust pan-European justificatory discourse has received less attention. Without discounting the importance of the former, in the next part I will seek an answer in the latter.

\section{Competition for the closure of deliberating communities}

In the first part of this article, I showed how the successive use of modus ponens and modus tollens can align the results from a premisewise and conclusion-wise decisional procedure in a group of three. For large groups, the alignment would take more rounds of such inferences which take place through the communication of justificatory arguments and counterarguments in what is known as the public sphere. This is not to say that communication alone would change initial beliefs, but only that it is an enabling condition for this to happen. In this paper I will set aside the question of when people are willing to engage in serious deliberation and eventually reverse their beliefs, to focus on the environment which makes this possible in the first place.

So far, I have contrasted collective reason to the 'popular will' without specifying the latter. I have taken it to mean the aggregation of in- 
dividual conclusions for the desirability of the proposed policies. This seems appropriate for many cases; for issues which are not salient and do not receive much media attention, citizens may form their opinions independently of each other. In such cases, the popular will is merely a function of their individual attitudes. However, people also discuss salient issues informally - with their friends, families, at parties, charity events or in sports clubs. Thus, they form what appears as individual opinions in deliberation with others and these opinions are at least partly shared within the respective discussion groups. In every democracy, while bills make their way through the respective legislative institution, they are informally discussed in the public sphere, and it is trivial to note that post-deliberation attitudes are different. Even if entrenched interests and pre-deliberative opinions strongly prejudice the resulting public opinion, the latter will at least be partly modified during the process of decision-making. Thus, popular will, properly understood, is an aggregation of post-deliberation attitudes, and in any event it is formed during the process. ${ }^{99}$ In this view, public or national interests are not exogenous, but are socially constructed in the process of public reasoning. ${ }^{100}$

More interestingly, the opinion of every individual will be affected differently by the different peoples he deliberates with, and as people can potentially deliberate in several overlapping groups, they are likely to be driven in conflicting directions. Group overlaps create tensions: a citizen may belong to and deliberate in two groups simultaneously, but when the different groups reach different decisions he cannot internalise both. Thus, even if a citizen identifies himself both with his nation and with Europe, he cannot come to believe that $p$ is true (so that he can support the collectively rational national policy $\mathrm{X}$ premised on $p$ ) and that $p$ is not true (so that he can support the collectively rational European policy $Y$ premised on $\neg p$ ). For example, it might be collectively rational for the EU to impose a tax on financial transactions and collectively rational for the UK to attract international banks to the City of London. Both of these policies are dependent, inter alia, on the premise 'banks can move away easily'. A Briton cannot believe that this premise is true so that the national policy is justified, and that it is not true so that the European policy is justified. While in principle he may be equally open to persuasion by his

\footnotetext{
99 This informal deliberation is not related (not directly!) with the collective reasoning discussed in the previous section. If the group is collectivising reason, its decisions may be different from either of the two opinions.

${ }^{100}$ For this view, see Trenz, drawing on John Dewey: Hans-Jörg Trenz, 'In Search of the Popular Subject: Identity Formation, Constitution-making and the Democratic Consolidation of the EU' (2009) 18 European Review 93. Actually, Trenz goes even farther than me to claim that discursive practices create identities and popular subjects. He considers the relationship between nested European and national identity discourses, but does not perceive them as being in competition, as I do.
} 
fellow countrymen and by his fellow Europeans, one of the groups will eventually prevail. As we cannot expect people's opinions to be malleable infinitely, we can expect that after a certain number of democratic iterations the opinions will stabilise and the persons involved will become less susceptible to further persuasion. Thus, the same person may end up with different post-deliberation attitudes depending on the order of these discussions (as well as on other contingencies), while the simultaneous processes of opinion formation in overlapping communities interfere with each other.

Consider one problem emerging in integration scholarship. As was discussed above, many researchers provide abundant evidence of cooperation and rational persuasion in the Council and the like. In many cases, however, for instance in GMO regulations, there are none of these, even though the conditions seem appropriate. One common culprit is the 'politicisation' of the issue ${ }^{101}$ and that '[domestic] public opinion severely limited the ability of member states representatives to engage in the ... deliberative search for better policy'. ${ }^{102}$ There is an air of uneasiness in finding the 'deliberation' between public officials to be at odds with deliberation in national public spheres, but there are numerous other studies which also identify 'politicisation' as a negative condition for reaching cooperative solutions. ${ }^{103}$

Pollack and Schaffer do not define 'politicisation' but emphasise that in their case-study there was a strong public opinion in some domestic constituencies, which constrained the agents and prevented them from reaching a collectively reasonable solution. To accommodate this and similar findings, I will take the 'politicisation' of an issue to mean that public opinion is formed and consolidated on a certain position so that deliberation is unlikely to change it any further. The issue is 'politicised' not only when it is decided at a political, as opposed to a technocratic, level, as there is significant evidence for cooperation at both levels, and examples of failures at both, too. It can be expected that if the domestic discussion has not yet ossified, the level or salience is not an obstacle to deliberation. Only when a certain single public opinion on the issue

\footnotetext{
${ }^{101}$ In their study, Pollock and Shaffer conclude that the deliberation ... has fallen victim to the widespread politicization of the GM issue'. See Mark A Pollack and Gregory Shaffer, 'Risk Regulation, GMOs and the Limits of Deliberation' in Naurin and Wallace (n 79) 149. 102 ibid 161.

${ }^{103}$ To avoid confusion, it is important to note that the term politicisation in integration scholarship has a different meaning from the one civic republicans have in mind. When Pettit speaks about politicisation and depoliticisation, he means the empowering of unelected institutions which are not representative in the traditional sense. It is in this sense that I have used the term until now, too. EU scholars use the same term for a salient issue, or one which is decided at a high level. The two senses of the term should be distinguished by the context, but to minimise confusion I put the word 'politicisation' in quotation marks when using it in the latter sense.
} 
is formed and this opinion is internalised as a common position of our group by an overwhelming number of its members would further deliberation be derailed. This position may be just an aggregation of individual preferences (pre- or post-deliberative) of group members, or it may result from a more subtle practice of collective reasoning, via deliberative institutions. However formed, the crucial difference in my view is whether this position is already internalised, ie whether a significant number of members have revised their initial positions accordingly. ${ }^{104}$

Public deliberation is the most democratically plausible cause of internalisation ${ }^{105}$ and the process has been observed empirically in various circumstances. ${ }^{106}$ On the basis of the available empirical literature, Cass Sunstein concludes that the 'effect of deliberation is ... to decrease variance among group members, as individual differences diminish'. ${ }^{107}$ Note that the group itself will often exist before and independently of the formation of the common will, but in some cases it may be constituted during the process itself - such is the case of many civic organisations emerging around a single cause. Whatever the method, when a position is formed its understanding as 'common' provides a separate incentive for members to internalise it. Thus, it consolidates and is closed for any further challenges, deliberative or other. As Sunstein observed, 'social ties among deliberating group members tend to suppress dissent ${ }^{\prime 108}$ and that is how a group may speak with a single voice for what is perceived to be the interest and will of all. Such a group may act as a singular agent with interests of its own, and naturally its actions are governed by instrumental rationality which uncompromisingly chooses the one best alternative. As the agency emerges out of the commitment to a certain purpose, it is unavoidably parochial; it cannot promote anything but this purpose. Normally, such a purposive agent would fail even to consider arguments relevant for any other interest but the promotion of its own purpose, and that is why for this agent the issue is effectively closed. ${ }^{109}$

\footnotetext{
${ }^{104}$ Note that the internalisation of the common will closes the rationality gap, as argued before. But the focus of this section is the common will, and its consolidation pertains both to groups which do and which do not collectivise reason.

${ }^{105}$ Other means to consolidate the common will may be tradition, sense of identity, religion, charisma, ideology, manipulation.

${ }^{106}$ Fishkin's studies are the best known. See James S Fishkin, When the People Speak: Deliberative Democracy and Public Consultation (OUP 2011).

107 Sunstein (n 29) 178: He also noted that this leads to the group moving to a more extreme position, which is precisely what Pollack and Shaffer observed.

108 ibid 181.

${ }^{109}$ Recall that according to List and Pettit, for a group to act as a single agent it must speak with a single voice and display integrity, so closure and agency appear to co-originate and constitute each other. See List and Pettit (n 6). This allows us to treat collectives as single agents; otherwise, it would make no sense to speak about collectives and states in the singular at all.
} 
There is no further deliberation internally, and members of the relevant group join efforts to act in pursuance of the common position and, if necessary, to guard it against external argumentative challenges. If a common position is formed but not internalised in such a sense, it would be unstable - external agents may appeal to the different inner groupings and change what will eventually appear as collective opinion. This is no longer possible when a singular group opinion is formed; such a group is an agent with a mind of its own.

I suppose that this is what routinely happens in nation-states when they define something as 'national interest'. Such interests are commonly perceived as something objective, but it is an open question whether, for example, it is in the national interest to protect a certain industry, thus favouring its owners and employees and disfavouring its consumers. Yet at a certain point of time a common opinion either way may form, winning the hearts and minds of most citizens. In principle, this may happen in many different loci - at the regional level, in minority or functional groups, etc. It can also happen at the supranational or indeed at any level. Although it is rare to witness consolidated public opinion at the European level, there was at least one example of such in the opposition to the Iraq war which famously prompted Habermas to announce the birth of the European public sphere and the European demos. ${ }^{110}$

Here is not the place to take stock of all the consequences of this closing, ${ }^{111}$ but the problem with the consolidation of popular opinions in multilevel decision-making systems, where the same citizens participate in several nested groups, should be apparent. As the collective opinions ontologically depend on the attitudes of the respective individual members, discourses at each level are effectively in competition with each other to form a consolidated collective of supporters. In the EU, the consolidated collective will formed at the national level precludes further deliberation at the European level, and vice versa. ${ }^{112}$

\footnotetext{
${ }_{110}$ See Jürgen Habermas and Jacques Derrida, 'February 15, or What Binds Europeans Together: A Plea for a Common Foreign Policy, Beginning in the Core of Europe' (2003) 10 Constellations 291. A decade later and with all the acrimony the Euro crisis brought, it is clear that the announcement was quite premature, but this does not undermine the claim that it is at least possible on a case-by-case basis.

${ }^{111}$ For example, such apparent group consensuses often protect hidden exploitation. See Chantal Mouffe, 'Deliberative Democracy or Agonistic Pluralism', Institut für Höhere Studien (IHS) Working Paper 72, Wien 2000 <www.ihs.ac.at/publications/pol/pw_72.pdf> accessed 19 November 2014.

${ }^{112}$ Note that despite the alleged commonality of values, etc, the opinions reached at each level are bound to be at odds with each other because the inclusion of different deliberators at the upper level leads to the introduction of different information and different considerations.
} 
In principle, scholarship on deliberative democracy maintains that the involvement of the general public (as opposed to interested stakeholders) prevents precisely this type of parochialism and closing. The general public is treated as a valuable source of knowledge of human needs and vulnerabilities. ${ }^{113}$ The problem is that national publics are not general with regard to pan-European interests; at that level, they become stakeholders without a pure public to correct for their pathologies. ${ }^{114}$ On the contrary, the pathologies may even be exacerbated when sectoral interests can exploit a history of capture of the national opinion to perpetuate their parochial interests, casting any contestations as offensive to the 'national interest'.

While I am not aware of any empirical research of 'polarisation' of opinions in simultaneous deliberation at various levels, it is a very plausible hypothesis that at each level public opinions form in competition between each other for the hearts and minds of the citizens. Given the limited time and attention of the latter, such competition is inevitable even in ideal conditions. If personal opinions were to change incessantly, the competition may continue ad infinitum, or perhaps the most general discourse would pre-empt all the others. In the non-ideal case, the malleability of individual opinions is finite and at some point individual opinions stabilise so a single common will emerges and the discourse proceeds no further. Closing allows the nations to speak in a single voice, which is a condition for their capacity to achieve goals, but it makes any further argumentative challenges inimical to 'national interests'. The closure creates a distinction between the perceived interests of the members of the nation from what may be the rival interests of others. ${ }^{115}$ The outcome of opinion formation varies according to the location of the boundaries of the deliberative space; within the boundaries, individual opinions tend to homogenise and polarise. ${ }^{116}$

Now, in the EU the interests of all European citizens should be taken into account, yet public spaces remain largely national and exclusion-

\footnotetext{
${ }^{113}$ Compare, however, with Bellamy and others (n 64), who make the point that the participation of stakeholders 'threatens to become partial and arbitrary in its representativeness of civil society' (147) and recommend nesting the participatory mechanisms in general (and representative) publics. See also the discussion in the previous section that collectively reasonable decisions need to account for the considerations of everyone affected.

${ }^{114}$ For the pathologies of partisan groups, see Cass R Sunstein and Reid Hastie, 'Four Failures of Deliberating Groups' (2008) University of Chicago Law \& Economics Working Paper No. 401; Sunstein (n 29).

${ }^{115}$ Compare the suggested notion of closing against deliberative challenges with Hannah Arendt's claim that democratic politics became possible in Ancient Athens only when the city walls were erected around the agora, thus creating a political space shielded from external challenges. See Hannah Arendt, The Promise of Politics (Schocken Books 2007).

${ }^{116}$ Note that deliberation leads not merely to internal convergence, but to 'convergence on a relatively more extreme point among predeliberation judgments'. See Sunstein (n 29) 178.
} 
ary. ${ }^{117}$ We may assume counterfactually that communication in a panEuropean public sphere emerging around the Union institutions would decrease variances in the individual wills of all the citizens (as it does in national spheres) and ideally produce European opinion, tending interests which are European. However, the existing internal borders create deliberating subgroups tending respective parochial interests. These subgroups not only find their opinions thwarted by EU decisions but they also impede the communicative process at the upper level which appears as an external challenge to them. ${ }^{118}$

The dialectic of homogenisation and radicalisation of deliberative groups puts the overlapping groups in competition with each other to form 'their' will and close themselves in protection thereof. Their success is likely to depend on the actual communicative practices, and in turn on the quality of the public sphere within each group. As George Vasilev notes 'in-group environments already have the discursive infrastructure in place through which mindsets can be altered [while] across-group communicative conduits are liable to be weak'. ${ }^{119}$ Most successful would be the groups which have created communicative conditions which enable them to form a position which is both prompt and appealing for all or most of the members. The construction of more robust and more inclusive public spheres is what determines the success of a group to reach a consolidated opinion, ie to formulate and protect an interest which is the group's own. Only in this way can they sustain their capacity to act in pursuance of their previously adopted goals without being constantly undermined by yawning rationality gaps. Note that closing the rationality gaps appears to be not only a matter of legitimacy but also of sustainability of the group. On the other hand, when public deliberation within the group fails to close it in this way, there is a window of opportunity for opinion formation at a different (higher) level.

Although will formation at national level is usually much faster, there are many cases where the issue is too technical, too uncontrover-

\footnotetext{
${ }_{117}$ Notwithstanding that there is a nascent EU public space. See Risse (n 71). He and several collaborators in a series of studies during the first decade of the century found that the 'same European themes are discussed at the same time at similar level of attention across national public spheres'. However, the overall attention paid to these issues remains low.

${ }^{118}$ European integration opens up decision-making institutions to external normative and argumentative interventions and may prevent the adoption of single-minded parochial decisions. However, this is not matched by a sufficiently robust opening of national public spheres. The yellow card mechanism mentioned in part two promises to contribute to the latter, but its efficacy is still to be seen.

${ }^{119}$ See George Vasilev, 'Preaching to the Choir or Converting the Uninitiated? The Integrative Potential of In-group Deliberations' [2012] Critical Review of International Social and Political Philosophy 1, 7. Vasilev continues to say that inside groups one can find the psychological and communicative infrastructure' which is sufficiently developed to allow 'transformative deliberation' ibid 19.
} 
sial or not sufficiently salient for national will to be formed. This is the case of 'uncertainty' which was identified by constructivist scholarship as another condition enabling deliberation. ${ }^{120}$ However, on the suggested account it is not the mere uncertainty but the availability of multiple voices in cases of uncertainty which makes a difference. ${ }^{121}$ The constitutional system of the Union generally opens national public spaces to external argumentative pressure, ${ }^{122}$ but the deliberative homogenisation of national opinions closes the borders again.

Another factor, often identified as an obstacle to cooperation, is publicity which should also be unappealing for the deliberative democrats. On the suggested account, publicity in the Council and in the related bodies will prevent cooperation only when consolidated will has already been formed at national level. Consolidated positions will prevail because they constrain the agents to defend them, even if they are argumentatively defeated. In contrast, when positions have not yet become a common article of faith, the arguments of the others may support the position of internal dissenters and the delegate may side with them to reverse the initial determination of the national interest.

If my argument is correct, then two major processes should be distinguished in the relations between the EU and the Member States. First, there is a process of collectivised reasoning (in the broad sense) at the Union level. Apparently, it leads to rationality gaps in all cases where contrary opinions are formed in national public spaces. Rationality gaps also open on many less salient issues on which no consolidated national will is formed, yet where a substantial number of citizens reasoning on their own have reached opposite conclusions. On many issues (perceived as technical or simply unnoticed), neither national nor individual wills are formed; there, EU policies will face indifference or mild support and no gap will open. The second process is one of public deliberation in the nascent pan-European public sphere ${ }^{123}$ which results in precious few examples of European public opinion tending pan-European rather than national interests. In principle, the latter process of opinion formation could provide the feedback loop and close the gap opened by the former process. However, pan-European opinion emerges well after the national

\footnotetext{
${ }^{120}$ See the contributions in Naurin and Wallace (n 79), for example.

${ }^{121}$ Note that uncertainty is not an exogenous factor but itself is a matter of perception: in the GMO controversy discussed by Pollock and Shaffer, the opponents of the technology believed that the effects of genetic engineering are uncertain, and the proponents that the effects are certain. This suggests that uncertainty is not (or is not only) a scientific matter. ${ }^{122}$ As Risse and Kleine note 'speakers could never be sure whether their audiences held national preferences, party preferences, European versus national ones, or simply personal preferences'. See Thomas Risse and Mareike Kleine, 'Deliberation in Negotiations' (2010) 17 Journal of European Public Policy 708, 16.

${ }^{123}$ See Risse(n 71) and also Risse and Kleine (n 122).
} 
opinions on the same issue have emerged from the more robust national public spheres. For the time being, the EU public sphere is bound to lose the competition for will-formation with the national public spheres, and therefore pan-European opinions are shared by very few individuals. The national discourses on one hand have already closed the rationality gaps between popular opinion and collective reason at national level, and on the other hand these formed national opinions frustrate the formation of pan-European opinion, thus preventing the closure of the rationality gap at the European level. Because of this competition, the latter gap is bound to persist as long as the conditions for public deliberation are better in national public spaces. Moreover, this is self-sustaining, as the quality of the public sphere at national level fosters communication there to the detriment of the development of the public sphere at the European level.

Thus, in my view, the democratic deficit of the EU is not a matter of weak representation as it is commonly perceived, but rather a matter of unidirectional representation. More participation would strengthen only the input side of the representative relationship, while the emerging rationality gaps can be closed by the justificatory discourse which goes in the opposite direction. In national public spheres, such gaps are closed by the standard accountability practices - governments and all public authorities explain and justify their decision, and some of the citizens are persuaded to revise their initial beliefs. Thus, governments who act in accordance with collective rationality and against the tide of popular sentiments get re-elected more often than not. In a recent study, Christopher Lord found that the quality of justificatory discourse within the EP is comparable to that in the Member States. ${ }^{124}$ However, at the European level, such justifications fail to achieve what they routinely do in the national context simply because citizens have already formed their opinions in the parochial national discourses.

In principle, public deliberation at each of the levels may be governed to avoid the untoward results of the competition which the EU is bound to lose. Jane Mansbridge has drawn attention to arrangements where group leaders negotiate not only externally but also internally within their groups. ${ }^{125}$ Ideally, leaders may use their place at the border of the deliberative groups and mediate between internal and external discourses until they are aligned and the gaps at all levels are closed. This might be the case with COREPER discussed above, where the representa-

\footnotetext{
${ }^{124}$ Christopher Lord, 'No Representation Without Justification? Appraising Standards of Justification in European Parliament Debates' (2013) 20 Journal of European Public Policy 243.

125 Jane Mansbridge, 'A Deliberative Theory of Interest Representation' in MP Petracca (ed), The Politics of Interests: Interest Groups Transformed (Westview Press 1992).
} 
tives cooperate to reach a reasonable solution externally, and take up the responsibility to reverse the national position by internal negotiations with their principals. More generally, Vasilev claims that limited communication across groups followed by extensive in-group discussion to reflect what has been said by the others may allow a solution even of the most fundamental conflicts. ${ }^{126}$ His empirical examples of such an internal-external dynamic of deliberation are very similar to what was shown to happen in COREPER. Interestingly, in Vasilev's cases, the issues are both salient and divisive so they provide a good counterpoint to a possible objection that COREPER appears to be so successful because it leaves all the controversial agenda items to the Council.

In the same vein, the new mechanism for cooperation of national parliaments discussed above is intended as a way to manage the competition for opinion formation. The greatest promise of the 'yellow card' is that it would bring the debate on a European issue within the national public space at an early stage, possibly before the position of the government is formed and the national opinion consolidates. There are many voices in a single parliament, and the contestation of a draft acquis at an early stage at the national level may prevent the formation of a single conclusion and single 'national' will. Thus, the mechanism can be expected to open the national decision-making process to deliberative challenges in cases where its conclusions are presently reached without much discussion in obscure agencies of the national executives. Most importantly, in order to raise a yellow card, the parliaments must cooperate and act together, which means that they would have to speak more of a European interest if they wish to recruit followers beyond the border.

Apparently, the contribution of such institutions for managing the competition to favour pan-European opinions is limited. The political leaders should play their part, too, and recently Habermas called them to take responsibility to mediate between the European and national public sphere and negotiate with their citizens support of the decisions which are necessary to save the Euro rather than to follow the received mandates. ${ }^{127}$ It remains to be seen under what circumstances leaders take such responsibilities, given their obvious interest not to go against the tide of in-group polarisation. As Bellamy and Castiglione note, such 'arrangements can also give elites incentives to maximise rather than reduce their differences and to solidify group differences rather than allowing them to evolve or reduce'. ${ }^{128}$

\footnotetext{
${ }^{126}$ Vasilev (n 119).

${ }^{127}$ Habermas, 'Bringing the Integration of Citizens into Line with the Integration of States' (n 36).

${ }^{128}$ Bellamy (n 40) 13, reference omitted.
} 
To conclude, in this part I have claimed that in a multilevel polity rationality gaps occur at each level, and each level of collective reasoning has to deal with its own frustrations. Contravening popular will is formed (by public deliberation or otherwise) where intended or where not intended. Wherever it is formed, it tends to consolidate and close against further deliberative challenges. While justificatory discourses may close rationality gaps in nation-states, in multilevel systems opinions may consolidate at a level different from the one that is actually empowered, and then deficits persist. In the EU, this seems to be the case.

\section{Conclusion}

One of the purposes of this article has been to expose a problem neglected in republican theory which I called the rationality gap. It may appear trivial to claim that collective reason deviates from popular will, but this goes against both the popular perception of democracy as government responsive to citizens' will and against the democratic theory which explicitly or implicitly equates democratic responsiveness with public reason and the common good. More importantly, the notion of the rationality gap prompts different understandings of the deficiencies of modern democracy - not as imperfections of the links between representative institutions and citizens which need to be strengthened, but as a fundamental contradiction which needs additional efforts to be resolved in the public sphere. Thus, the problem with the gap does not undermine civic republicanism, it only makes deliberative democracy a necessary complement to it.

The other goal has been to suggest that republican theory provides a better understanding of the EU. This is not to propose yet another label claiming to capture the nature of the beast - the actual institutions can be interpreted in many different ways. I 'portrayed' it as a collectively rational agent to throw some new light on a much discussed problem: from such a perspective the democratic deficit appears to be an instance of the rationality gap, and there is no pan-European democratic discourse to close it. As such gaps arise from the logical inequality between collective and individual rationality (both of which have good normative and practical claims to prevail), they are experienced by all polities. Thus, the democratic deficit of the EU is a logical necessity rather than an institutional contingency ${ }^{129}$ and the host of institutional reforms which have been proposed to solve it are bound to fail even if they succeed in linking its institutions to the citizens more tightly. More citizen participation is certainly to be welcomed, but if it is true that rationality gaps may ap-

${ }^{129}$ Even though much of the literature on judgement aggregation is in terms of different decision-making procedures. 
pear in any group which collectivises reason, the increased input will not solve this problem because majorities which oppose what is collectively rational remain possible. The only way to resolve such tensions is to persuade such majorities to accept what is collectively rational. Unlike the other polities which presumably experience the gaps but close them by democratic iterations, the European Union cannot do this because its public remains fragmented.

Thus, rationality gaps are closed when the beliefs of the citizens change during the decision-making process. While citizens may or may not internalise collective decisions (and their reasons to do so vary), this happens in a step-wise process of communication in the public sphere. In this way, common opinions are formed and they become entrenched as 'national interest'. My suggestion is that nation-states, albeit rationalised decision-makers themselves, do not experience acute rationality gaps because they are closed by deliberation in their robust public spheres. When this process is successful, citizens identify the collective position as their own and revise their own initial beliefs accordingly. When a certain level of coherence is reached, the communicative process is closed to further discursive challenges. This could potentially happen at the European level by communication in the nascent pan-European public sphere; however, this discourse is usually pre-empted by the competitive discourses in the public spheres of the Member States. As the communication there is more robust, citizens form their opinion there first and close themselves for further discourses from without. As deliberating groups tend to polarise, the formation of internal common opinion derails the simultaneous communicative process at EU level. Again, the notion that European public opinion forms in competition with national opinions may appear trivial, but most advocates of multilevel democracy assume they are independent or complementary and certainly not rivals. It is also commonly assumed that communication and participation may democratise all levels of a multilevel polity. If the argument developed in the last part was correct, we cannot systematically have decisions which are both collectively rational and supported by the majority of citizens at each level, even in the best of circumstances.

The single most important conclusion we have to make is that the mismatch of collective reason and popular will is not simply an institutional problem. In the case of the EU, its democratic deficit is commonly perceived as a problem with representation, but in my view the problem is not on the input side. It is a failure of the feedback loop, and the solutions should be sought in the directions of better communication and justification. This is not to say that better representation and more participation are not necessary, since of course they are. Yet, as long as EU decision-making is not embedded in a robust public sphere which can 
generate pan-European public opinion in support of certain policies, the deficit will remain.

Although the paper is intended to offer better understanding rather than solutions to the problem with the European democratic deficit, two possible ways out emerge. The first is to integrate national public spaces by connecting them into a network so that the justificatory discourses on policy issues spill from one national public sphere to another. Even if citizens deliberate mainly locally, discourses may be connected so that the issues and arguments transcend the national boundaries and ideally produce genuine pan-European opinions. ${ }^{130}$ Apparently, institutional design can only be of limited help - institutions may create incentives for citizens to communicate across borders and foster the robustness of the pan-European public sphere in the long run. But there is hardly a way for any democratic institution to force opinion changes on citizens or to forestall the consolidation of their opinions in the 'wrong' place; so the tensions are bound to remain. The second is to take up the challenge and compete: whenever EU institutions identify a problem and reach a decision before a contrary opinion is formed at another level, they have a chance to justify it to the citizens so that they revise their beliefs and the rationality gap closes at the European level. Arguably, this may be the case on a number of issues which are not salient in any of the Member States; but we are still to see such an issue becoming salient at the European level. Although the first option may seem utopian, neither of the two is radical and in any case neither requires major constitutional changes.

${ }^{130}$ For such expectations, see Richard Bellamy and Sandra Kröger, 'Domesticating the Democratic Deficit? The Role of National Parliaments and Parties in the EU's System of Governance' [2012] Parliamentary Affairs 1-21. 
